\title{
Direct Displacement Based Design of RDC Frame-Shear Wall Structures
}

\author{
Can Balkaya*‡, Ali Etemadi**, Öznur Genç** \\ * Department of Civil Engineering, Istanbul Aydin University, Istanbul, Turkey. \\ **Department of Civil Engineering, Faculty of Engineering and Architecture, Istanbul Esenyurt University, Istanbul, Turkey. \\ (canbalkaya@aydin.com.tr, alietemadi@esenyurt.edu.tr, gencoznur@hotmail.com) \\ $¥$ Corresponding Author; Can Balkaya, Department of Civil Engineering, Istanbul Aydin University, Istanbul, Turkey, \\ Tel: +90 4441428-22816, Fax: +90 (212) 4255759, canbalkaya@aydin.com.tr
}

Received: 15.10.2020 Accepted: 14.08.2021

\begin{abstract}
A large part of Turkey's urban region is located in the seismic prone zone and in terms of population, the majority of densely populated cities are located close to near-fault regions. It is very important to determine the behaviors of structures against external forces after destructive earthquakes. Structural and non-structural damages that occur during the earthquake usually arise from lateral displacements occurring in the structural system. This is why, in recent years, the displacement-based design has become more important when compared to the force based design. In this study, the Direct Displacement Based Design method under earthquake forces are explained. The process steps of this method on a frame-wall structure are clarified. The dynamic behavior of a moment resistant structures and a combined system with shear walls are compared. The finite element method used to analysis of reinforced concrete building models. Some model with moderate and high vibration period is adopted for dynamic analysis. An arrangement of the shear walls is changed in story plan of models. The dynamic analysis has shown quite different response among the structural systems. The difference in dynamic behavior is coming from the interaction of dynamic response between shear walls and moment resistant frames. Furthermore, the important role of shear walls displacements in transferring lateral loads is clarified with numerical examples. The positive role of RC shear walls on the combined structures under earthquake forces has been emphasized.
\end{abstract}

Keywords: Displacement based design, interstory drift, shear walls, finite element method

\section{Introduction}

Considering the earthquake reality; the necessity of designing more reliable and strong constructions cannot be ignored. This is where the performance of displacementbased performance comes into play. Structural investigation and design based on design provisions have been elaborated and improved during the investigation of strengthening structures that are primarily concerned with determining the earthquake resistances against earthquake hazards more realistically and not providing adequate safety. It is also important to determine which method is suitable for designing earthquake resistant structures. Displacement- based design methodology ensures that damage to the structure can be determined in a more realistic way. This research is gaining value at this point. This method, which has been mostly studied over the last years, is enriched by putting new researches on each passing day [1,2].

The displacement ductility, strength and rigidity criteria required to design an earthquake resistant building are described. In order to investigate the relative story drifts of the wall - frame systems numerical examples are given and building analyzes are made. The calculation methods are shown step by step to explain how to analyze the sample buildings. The 6 and 12 stories have been applied to the structures with six different story plans, stiffness distribution 
pattern is created and the numerical calculation of the base shear forces is shown. The wall-frame systems are totally superimposed over shear-wall or completely frame systems. Story displacements and relative interstory drifts analyzed by using the finite element analysis IDESTATIC program [3] and mode superposition method are found. Reinforced concrete walls also compensate story displacements due to the rigid structure. This reduces the total displacements throughout the building height. According to analysis result the relative interstory drifts and story displacements that showed the positive effect of the compared shear- walls on the system and checked that they did not exceed the targeted rates.

Recent developments in an earthquake and structural engineering have brought a different approach and energy to these views, which are known as common engineer approaches. Since 1995, as a result of earthquake and structural engineering, it is determined that the concrete column shortening story and building lateral displacements from the principle of "Strengthening (or Force Based) Design" based on the values of bending moment, normal force, shear force, and seismic performance values, (or displacement, change of shape, displacement) of buildings based on their values, based on the values of the unit elongation and the shortening of the equipments and the seismic performances of the buildings can be mathematically determined. Structures generally do not provide clear information on the Force-Based Design approach. Although these codes give some information on the damage status of the building elements, they give only very limited information on the damage status of non-structural elements and systems. Displacement Based Seismic Design, a new concept in seismic design of constructions, is a reliable approach that can provide more detailed information about the performance levels of both structural and nonstructural elements.

Since they are the main elements providing lateral stiffness, reinforced concrete shear walls and their behavior are of vital importance in ensuring structural safety under lateral altering. The structural safety of reinforced concrete buildings under lateral effects is ensured by reinforced concrete shear walls. The system, which is designed with frame and shear wall carriage together and called shear wallframe system, is designed in order to meet the considerations of covering a significant part of the lateral forces coming into the structure through the shear walls.

In this study, a linear displacement-based design procedure is described for shear wall-framed structures. In its most general form, shear walls are elements carrying lateral loadings. The direct displacement-based design method describes the design of shear wall-frame type structures based on displacement and the effect of shear walls on displacement. In direct displacement-based design method based on shear wall-framed systems. Instead of a multi-degree-of-freedom structure, a single-degree-offreedom analysis method that performs the solution together with the structure is used. The aim of this method is to show the displacement profile damping components for the shear wall-frame type structure as a single degree of freedom system and make the system design as applicable as possible by reducing the base.

In this study, it is aimed to evaluate how the effect of shear walls in reinforced concrete buildings or the contribution of lateral forces is clarified on the basis of the Direct Displacement-Based Design method. For this reason, five different reinforced concrete moment resistant systems have been analyzed. The building consisting of 6 different types of reinforced concrete shear wall-frame system with 6 and 12 stories is analyzed. IDESTATIC platform is used in evaluating earthquake performances of structural models. As a result of the analysis made by the Mode Contribution Method, the displacement values and the effects of the shear walls on the design of the structure are observed. The displacement values are calculated and compared for the earthquake ground motion effect with a probability of exceeding $10 \%$ in 50 years. In the calculated target displacement value, the plastic rotations of the column, beam, shear walls are firstly calculated, then the relative interstory drifts between two consecutive stories are calculated. The relative interstory drift results are compared with the limit values given in the current earthquake regulations.

The concepts and criteria of displacement-based design are described in detail in specifications such as ATC 40 [4], FEMA 273 [5], FEMA 356 [6], FEMA 440 [7], ASCE / SEI 41 [8], CEN (EC8) [9], TEC [10] and TBDY [11]. These regulations, which have a lot of similar features and benefit from each other, briefly describe the static calculation bases and criteria that take into account the plastic movements under earthquake forces of buildings and explain the related performance levels to be used for determining the possible damage rates of the structural members following the dynamic analysis and their evaluation methods.

Nowadays there are many researches on displacementbased design are available in the literature: Shibata and Sözen [12] presented the substitute structure method for ESD systems. Replacement Method for Reinforced Concrete Structures was a method used to determine the design spectrum and design forces of earthquake motion. This method has been used by Priestley [13] and Priestley [14] to create the "Direct Design by Displacement" method that is using in practice. The capacity spectrum method given in ATC-40 [4] modified by Hong and Cho [15].

Priestley et al [16] described the basic principles and main outcomes of the displacement-based design. How to convert complexity systems multiple degrees of freedom into 
an equivalent single degree of freedom system. A method describing the modal motion of symmetric and asymmetric buildings was presented. 6, 12 storey reinforced concrete structures were applied on the method in the building type results were investigated. This method was called the Direct Displacement Design (DDED) [17].

Kowalsky et al. [18] proposed displacement based design method when designing reinforced concrete structures and bridge piers. Single degree of freedom structures and bridge columns are examined and compared based on displacement. They take pier strength and stiffness as the basis, and they regard the strength and stiffness in the method as a result of the method, not variable. The DDBD procedure reinforced concrete frame and steel supports was investigated. Three identical structures were made with different heights. To verify the procedure of such structures, a nonlinear time history analysis was applied. The results obtained from the nonlinear time history analysis shown that the DDBD procedure was very effective for the seismic design of such structures $[19,20]$. Another application of the Direct Displacement-Based Design (DDTT) approach as one of the PEST procedures, has been demonstrated by Karimzade and Aktas [21]. Relative story drift ratios were used to describe performance levels at given earthquake levels. Capacity design principles were also followed to ensure ductile behaviors of plastic hinges on the exterior beams from the columns. Analysis has been carried out to check that the relative interstory displacements do not exceed the targeted rates.

Abhyuday [22] studied on the importance of structural displacement during the design of structural and nonstructural elements, also presented a fundamental description of the Direct Displacement Based Design (DDBD) procedure (as proposed by Priestley [16]) together with its advantages and limitations over the conventional Force Based Design (FBD) method. The various performance levels were investigated and accordingly a methodological statement of the DDBD method was dedicated for computing the amount of base shear. Unlike FBD, in DDBD the limit states were not controlled, rather those were applied as an input data. Accordingly, it was indicated that the DDBD was simple and more economical than the conventional FBD method. It is believed that in the coming years the DDBD method will be adopted in whole and that it will be used as a solemn alternative method by its simplicity and advantages.

Lopes et al [23] used a way pushover analysis, so-called $\mathrm{N} 2$ method, for the seismic vulnerability evaluation of various building typologies. The opinion of reversing the N2 method in a direct displacement- based design was not new and currently adopted in the Annex B of Eurocode 8. the procedure proposed in this paper offers an easy alternative form to calculate the ratio of the seismic action regarding to any performance level and to specify the target displacement without the need for an iterative process. The procedure proposed will provide the opportunity to evaluate graphically of how a structure will behave when exposed to strong ground motion.

Yan and Gong [24] conducted an adaptive pushover analyses for sixty-six RC frame buildings with characteristics in order to calculate the distribution of lateral displacement, and in turn an altering law of plastic hinge distribution and deformation mechanism. As result, displacement profile expression in design considering multiple performance objectives was proposed. A practical displacement-based framework for seismic design of flexible-base structures subjected to near-fault pulse-like ground motions was presented by $\mathrm{Lu}$ et al [25]. An equivalent fixed-base single degree- of-freedom oscillator is adopted to capture the salient features of an actual soilstructure interaction (SSI) system in order to facilitate the design process. Two step-by-step direct-displacement based design (DDBD) procedures based on compatible inelastic spectra and equivalent linearisation were introduced. The results of this study suggest that the procedure based on inelastic design spectra, in general, provides a better design solution than using an elastic linearisation method, especially when structures were designed with a higher ductility demand.

In this study, the principles of design for displacement are explained and the stages of direct displacement-based design of shear wall-framed structures are explained steply. The basic concepts including performance-based calculation methods in current provision are investigated. Following evaluation of in the behavior displacement ductility, the effect of shear walls on reinforced concrete structures in the design for displacement is defined as the elements which increase the lateral stiffness and numerical examples are given on five buildings with 6 and 12 story shear wall-frame system. Shear wall-frame type structures are given by direct displacement-based design method; it is aimed to show the effects of lateral walls on shear walls. Idestatic V.8 analysis platform has been analyzed on building models. As a result of the analyzes; the examples are based on some assumptions and the solution has shown that the existing shear wallframed structures reduce the displacement results and the relative story drift of shear wall use.

\section{Modeling and Method of Analysis}

Displacement-based design, as the basic idea; the form of the seismic design which is the basis of the method considered in the calculations of the displacements (deformations) in the structures. In direct displacementbased design method based on shear wall-framed systems; instead of a multi-degree-of-freedom system, a singledegree-of-freedom system analysis method that performs the 
solution with the structure is used. The aim of this method is to develop the displacement profile damping components for the shear wall-frame type system show as a single degree of freedom system and to make the system design as applicable as possible by reducing the errors.

The prominence of the representation of an equivalent single degree of freedom; the inelastic properties of a multidegree-of-freedom structure under the earthquake forces can be incorporated into a simple model design. The effective displacement of the structure, the equivalent viscous damping function, the effective period and the design behavior spectrum are obtained using an equivalent TSD system. The displacement behavior spectrum can be calculated using different stiffnesses and masses in the TSD system. Therefore, the equivalent system approach should be used together with the displacement behavior spectrum. In a subsequent step, the effective stiffness can be calculated using the effective period. When the calculation resultant effective stiffness is known, the base shear force can be calculated. As a result, the multi-degree of freedom structure can be designed by distributing base shear forces over the building height.

Shear wall-frame type buildings are structures that use both framed and shear walls to resist earthquake motions. A special design methodology can be used for a structure of this type is required. Generally, shear wall-frame type structures are known as combination of two-system. Because the behavior of such a designed carrier system is quite different from the systems consisting of only frames or only shear walls. While the differences in the calculations, usually in the designs, are attributed to the interaction of the frame systems, the shear walls did not take up enough space in practice. The combination of shear walls and moment resistant frames combined with the building system is a very efficient and useful way to resist earthquake forces. The shear walls and frames used together to provide significant advantages over systems that consist entirely of shear walls or frames. Particularly shear walls are very convenient elements for controlling relative inter story drifts.

Shear walls limit the deformation of upper stories of buildings are limited. Reduces the total number of placements that the structures are experiencing. From an aesthetic and functional point of view, the frames provide a wide range of space for not restricting their use. They are, however, useful elements for protecting against fire and forming stairs in shear walls [26].

For shear wall-frame systems, shear wall rigidity should be reduced in the lower sections of the shear wall due to the equivalent system method. Base moments which are formed in the ground story columns are calculated according to the base shear force value of the column and the shear walls. After the shear wall moments are calculated from the shear wall-column stiffness ratio, such that all the data required for the static analysis is calculated. 


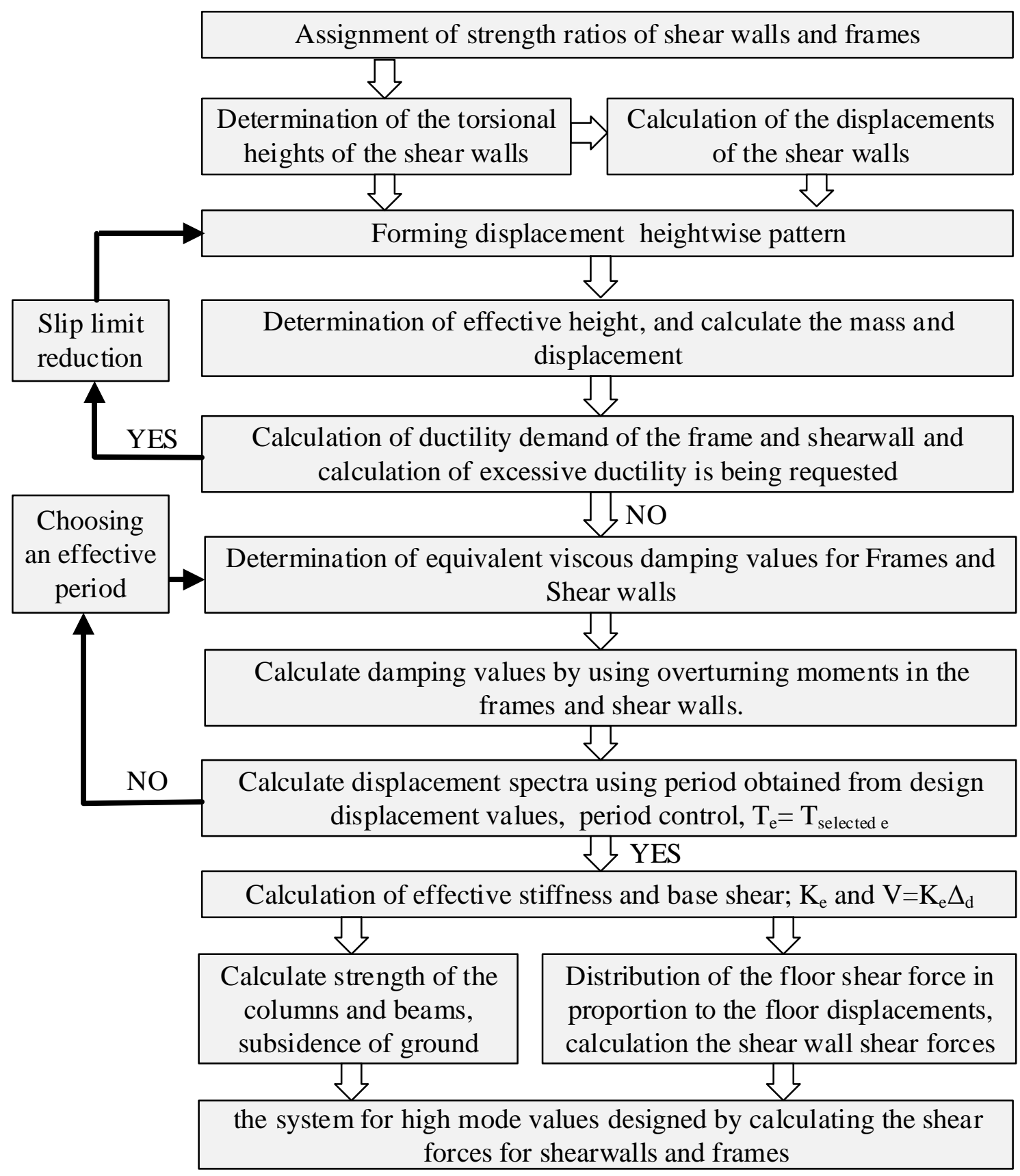

Fig. 1. Flow chart of the proposed design process for Shear wall - moment resisting frame system [17, 27].

The contribution to tolerated forces the continuous columns about weak beams is very limited. The capacity requirements must be met by the columns on the other axes.

\section{Analysis of $\mathrm{R} / \mathrm{C}$ frame-coupled wall structural models}

In this section, reinforced concrete buildings built with a shear wall-frame system with the same story plans of 6 and 12 stories and with/without shear walled buildings with 6 stories with different story plans are subjected to static analysis, relative interstory displacements are calculated and
The contribution to the strength of the structure of the columns on the (weak) axis with the beam discontinuity is very small. The stiffening and stiffness requirements must be fulfilled by the columns on the other axes

distributed profiles of displacements over the height are created. Analyzes are made using the IDESTATIC 8 structural analysis program. The shear walls placed opposite each other at the mid-axis of the structures are connected to each other by beams. In addition, the effect of the shear walls placed at corner points on different story plans has been examined separately. The interaction between the moment resistant frame and the shear-wall of the importance of 
structures connected together by the beams is important. The level of life Safety is considered as the story displacement limit.

\subsection{Structural Properties of Structural model}

The structural properties of building models are defined here; the story dimensions are $30 \times 18 \mathrm{~m}$, the story heights are similar and equal to $3 \mathrm{~m}$ in all stories. The moderate and high rise building models (6 and 12 stories) are used. The shear walls with the different arrangement are considered as well. Therefore, five different models are adopted to evaluate displacement demands. Since the buildings are thought to be residential buildings, the building importance coefficient is used as $\mathrm{I}=1$. It is built in Istanbul in the 1st seismic zone. Local ground class Z4 type and $\mathrm{C}$ group soil are adopted according to TEC 2007 provisions. According to Z4, the spectrum characteristic periods are $\mathrm{TA}=0.20$ and $\mathrm{T}_{\mathrm{B}}=0.90$. The concrete grade is $\mathrm{C} 25$ and the $\mathrm{S} 420$ steel grade used for longitudinal reinforcements. The cross-section area of the columns with $45 \times 65 \mathrm{~cm}$. All the beams in the building are the same size with $25 \mathrm{~cm} / 50 \mathrm{~cm}$, the $15 \mathrm{~cm}$ slab height even though the openings are large.

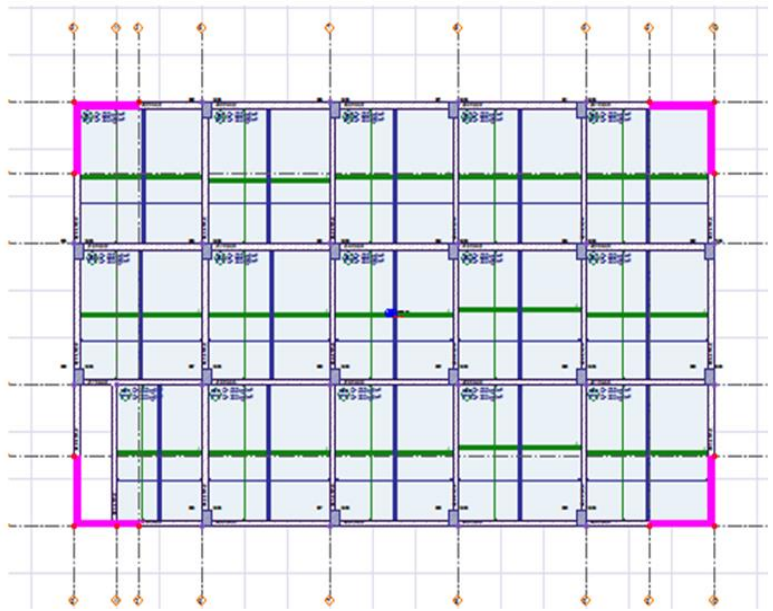

(b)

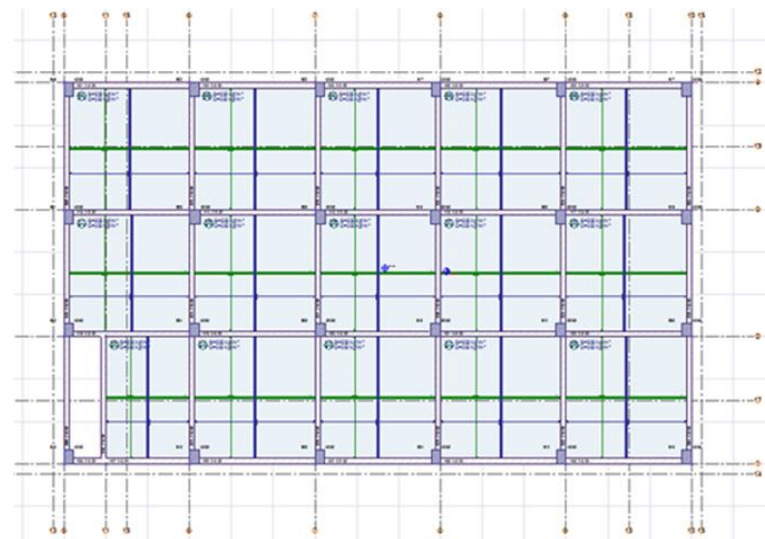

(c)
Fig. 2. Plan view of structures with and without shear wall

(a) 


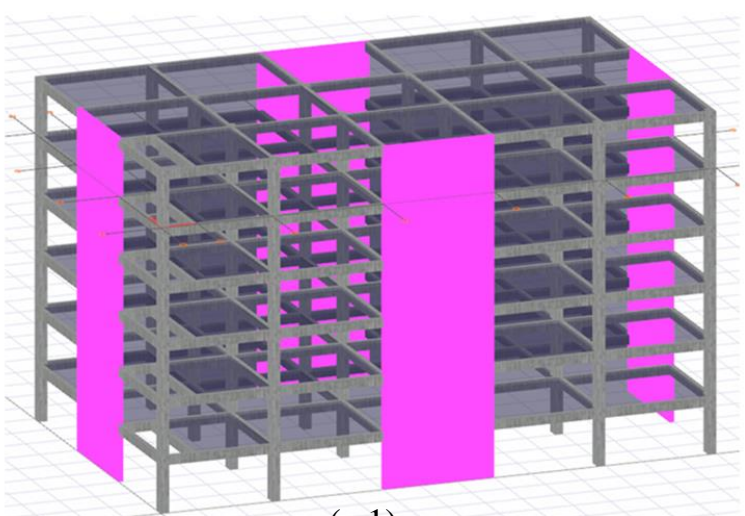

(a.1)

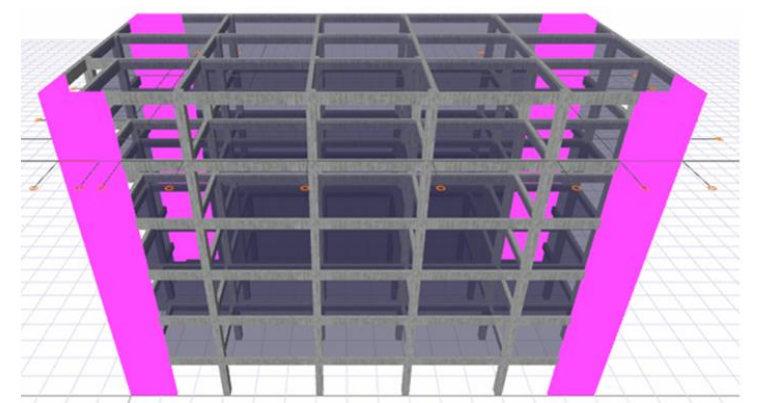

(a.2)

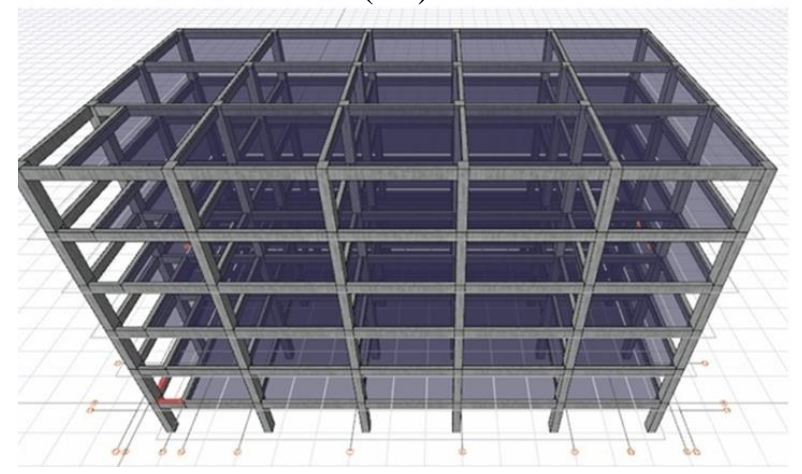

(a.3)

6 story Building

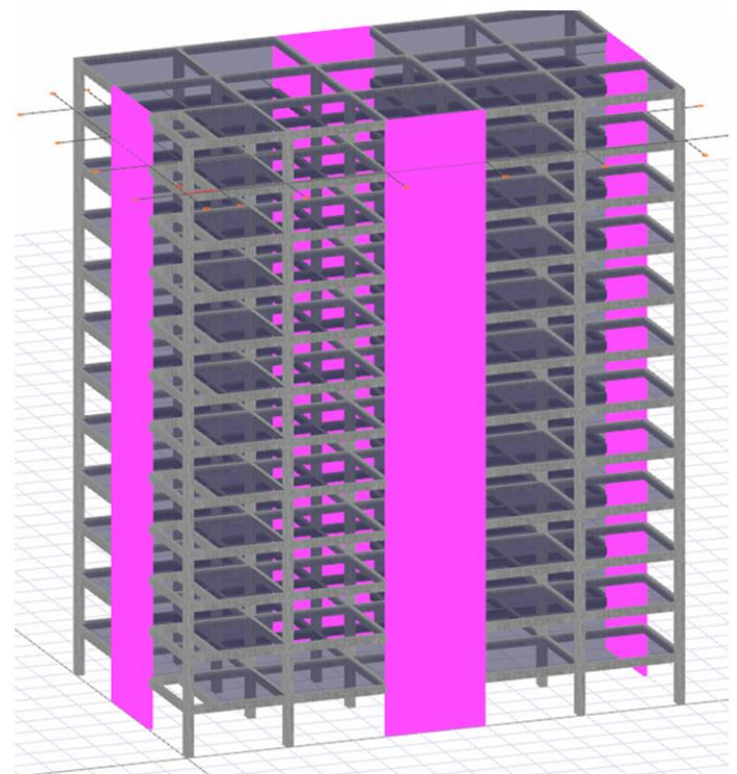

(b.1)

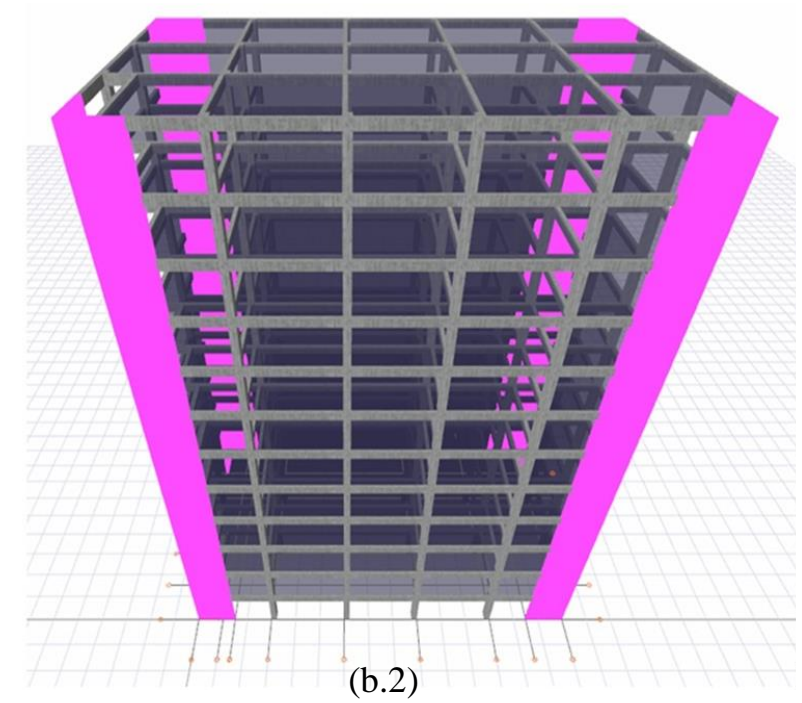

12 story Building

Fig. 3. Schematic 3D view of 6 and 12 story RC buildings 


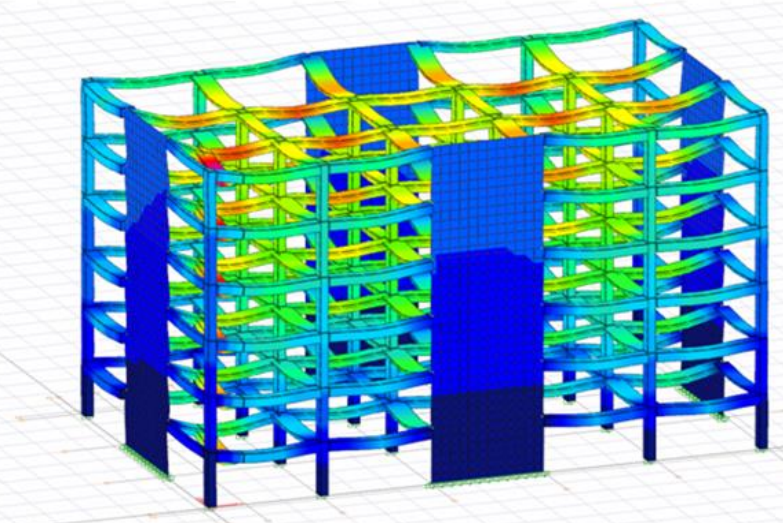

(a)

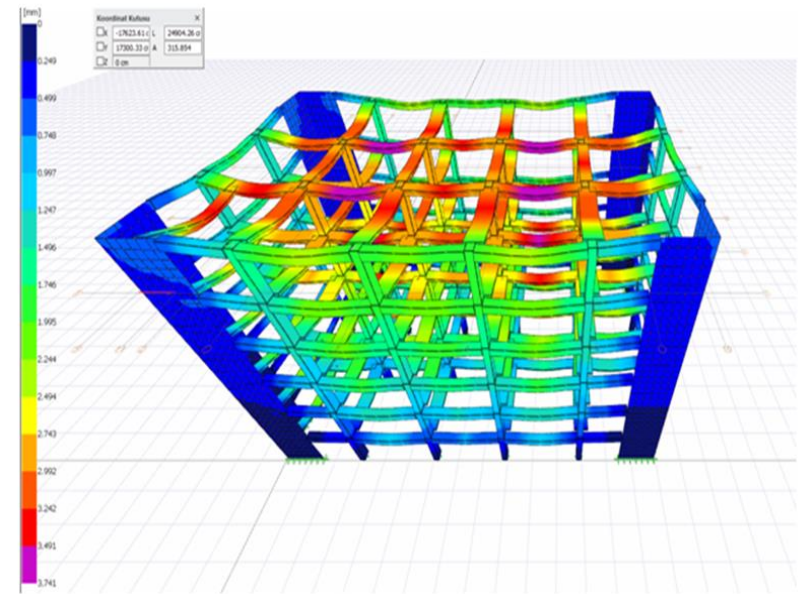

(b)
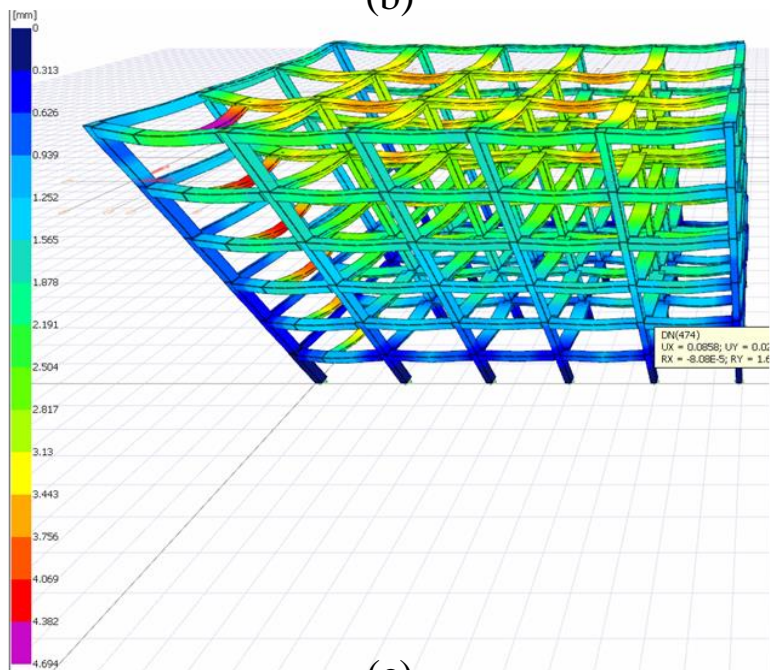

(c)

Table 1. The values of base shear force, displacements and relative interstory drifts for 6 and 12 story buildings with a different story plan

Fig. 4. Deformation of 6-story structural system with and without shear Wall

6 Story building

12 Story building

\begin{tabular}{l|cc}
\hline Length of shear wall $(\mathrm{cm})$ & 600 & 600 \\
Shear wall thikness $(\mathrm{cm})$ & 25 & 25 \\
Beam dimensions $(\mathrm{cm})$ & $25 * 50$ & $25 * 50$ \\
Column dimensions $(\mathrm{cm})$ & $45 * 65$ & $45 * 65$ \\
Story height (m) & 300 & 300 \\
Total weight of building (kN) & 2702 & 5552,39 \\
Total mass of building (ton) & 275,4 & 561,20 \\
Total building height (m) & 18 & 36 \\
Slab thickness $(\mathrm{cm})$ & 15 & 15
\end{tabular}

\section{Dynamic Analysis results}

The dynamic responses of 6 and 12 storey building models with shear wall - frame system and 6 storey moment resistant frame system listed in Table 1. For shear wall systems; the analysis results for the cases where the shear walls are placed in the central axis of the building and placed at corner points of the building are given in detail.

It can be said that the shear walls placed symmetrically on the exact middle point of the building with movement from the table, limit the displacements and drifts more than the corner points. When the number of stories changes from 6 to 12 , displacements and displacements in buildings are 
changing in such a way that the displacements are increasing at a level that can be tried 1 to 6 times. Relative inter story is increasing in displacement, but the ratio remains as 1 to 3 times. When the shear walls are removed from the center, it is seen that the displacement and interstory drifts are very high when looking at the 6 story building. This shows us how much the shear walls balance the relative story drifts in the combined systems.

Shear wall curvature demands are high and story drifts must be reduced to ensure that the design material stress limits range in 12-story buildings.

Shear wall - Final design forces for framed structures may depend only on the mass and story stiffness of the base shear force; demonstrates that design can be simplified to a significant amount without changing its mood. For the structure being analyzed, the longitudinal reinforcement ratios are used to improve strength capacity.

Under the lateral seismic forces, the most important indicator of building rigidity is the rate of relative displacement in which an individual element has its own rigidity and interstory drifts. In the Earthquake Regulations, relative to the features described as relatively displaceable during the earthquake. For one of the two earthquake directions perpendicular to each other, the torsional irregularity coefficient, which is the ratio of the highest relative story drift on any story to the mean relative drift on that story in the same direction, is greater than 1.2 , is called Torsional Irregularity. Care should be taken to prevent torsional irregularities, such as shear walls, etc., where rigid support system components are installed to increase torsional stiffness of the load carrying system [28].

As a result of the analysis made in the sample building, the data belonging to the structure are obtained; The details of the shear walls and columns of the 6 and 12 storey buildings are shown in Figure 1 and Table 1. Section dimensions and reinforcement detail are listed in Table 1.
Relative interstory drifts and story displacements are calculated for models with similar story plan, same story height but for twelve-story structure model. As a result of the analysis with Mode Combination Method, it has been observed that the displacement approach based on the displacement based design approach is very successful at the limit point. Interstory drifts are directly related to deformations, so they show a similar tendency.

Since the shear walls are restrictive elements for lateral displacements, the displacement values of the buildings are compared while investigating the behavior patterns of the different systematic buildings. The addition of shear walls to the system greatly reduces drift.

When the mentioned structure is evaluated in terms of relative story displacements for both systems, it is seen that story drifts in the shear wall system are balanced to a considerable rate. Story drifts that occur especially on the ground story are reduced. We can say that the shear walls are the elements that reduce the displacement of the relative interstory drift by their rigidity.

As a result of our analyzes on five different buildings with different story plans; how the use of shear walls, the location of the shear walls, and the relative story drift rates of the stories are affected. As can be seen in Figure 2, symmetrical systems in which the shear walls are located mutually in the middle axes according to their apparent shear force values are the most reliable systems in terms of tolerating relative story displacements. Similar results are obtained for 6 and 12 storey buildings, and the displacement values are more limited than the other systems. In the moment resistant frame system, the relative story displacement is similar for both the 6-storey and 12-storey buildings, although it achieved the base shear force. This clearly shows that the shear walls are very effective elements in limiting the relative interstory drifts. 
INTERNATIONAL JOURNAL Of ENGINEERING TECHNOLOGIES-IJET

Balkaya, Etemadi and Genç, Vol.7, No.3, 2021
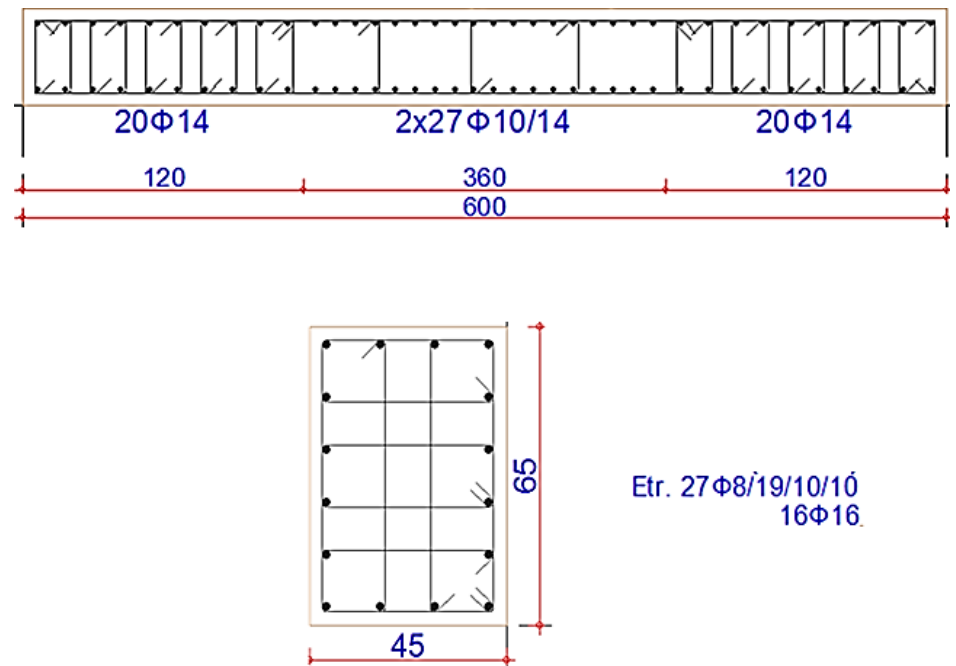

Etr. $27 \Phi 8 / 19 / 10 / 10$

$16 \Phi 16$

Fig. 5. Dimension and reinforcement detail of shear-wall and column used in 6-storey building model

Table 2. The values of base shear force, displacements and relative interstory drifts for models with different story plan and a different number of stories.

\begin{tabular}{|c|c|c|c|c|c|}
\hline & $\begin{array}{c}\text { 6 Story shear wall } \\
\text { at middle }\end{array}$ & $\begin{array}{c}\text { 6 Story shear wall at } \\
\text { corner sides }\end{array}$ & $\begin{array}{c}\text { 6 Story without } \\
\text { shear walls }\end{array}$ & $\begin{array}{c}\text { 12 Story shear walls } \\
\text { at corner sides }\end{array}$ & $\begin{array}{c}12 \text { Story shear } \\
\text { walls at middle }\end{array}$ \\
\hline $\begin{array}{c}\text { Total weight of structure } \\
\text { (ton) }\end{array}$ & 2759,35 & 2795,74 & 2617,23 & 5552,39 & 5498,68 \\
\hline $\begin{array}{c}\text { Base shear force at X } \\
\text { direction (kN) }\end{array}$ & 424,51 & 430 & 402,65 & 772,60 & 766,12 \\
\hline $\begin{array}{c}\text { Displacement (mm) } \\
\text { Maximum interstory } \\
\text { drift (mm) }\end{array}$ & 9,17 & 11,10 & 26,20 & 61,70 & 57,64 \\
\hline
\end{tabular}

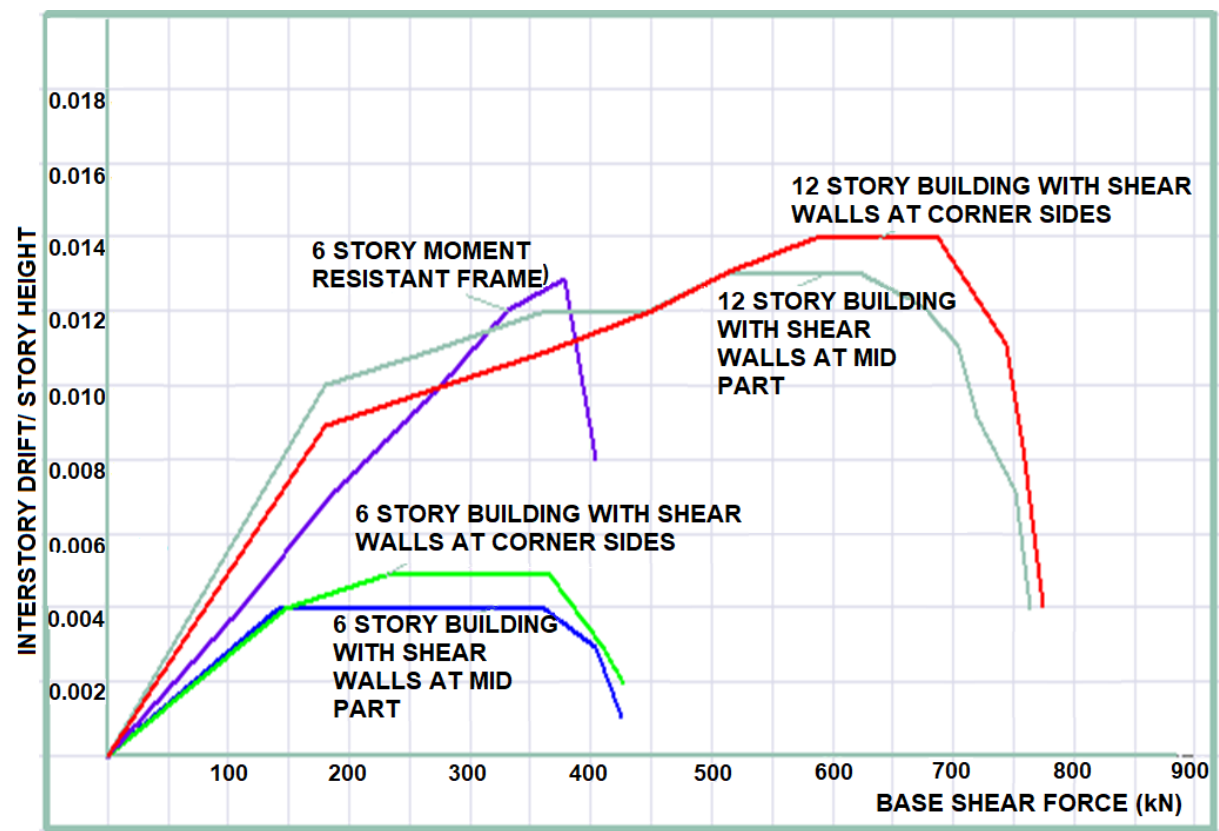

Fig. 6. Shear Stress and interstory drifts values on the basis of the load carrying System 


\section{Conclusions}

The displacement-based design method used to develop the displacement profile damping components for the shear wall-frame system represent as a single degree of freedom system and to make the system design as applicable as possible by redacting the drawbacks. The analyses results showed that; the displacement-based seismic design method provides perfect control of displacement and a reliable approach to interstory drifts in shear wall-framed structures. This design method is applied to 6 and 12 storey building with shear wall - frame system. The Finite element IDESTATIC 8 analysis platform is adopted for structural response analysis. Displacements and relative story drifts are handled separately for shear wall and moment resistant frame cases in the examples and where the shear walls are placed at different positions. The variation in story plans and layout pattern of shear walls are adopted to change the distribution of story rigidity and story strength of building along the building height. Interstory drifts rates are used to represent performance levels under the ground motions. Peak displacements, base shear forces are investigated as well. The structure is increased in effective periods as the building height increases due to the number of stories.

In this thesis study, six and twelve storey reinforced concrete buildings are used in determining the seismic performances of the system. Different buildings are analyzed as shear wall-frame system by placing shear walls in $\mathrm{X}$ and $\mathrm{Y}$ directions. As a result of the analysis, the performance levels are determined. Table 2 gives about relative story displacements and twisting of structures. Shear walls used in shear wall-frame system are used in X and Y direction. These shear walls contribute to the lateral load carrying capacity of the system. In addition, the contribution to the balancing of relative story displacements is large. As a result of the analysis, it can be said that the shear walls placed symmetrically at the exact outer mid-point of the building are more restrictive than displacements and displacements compared to those placed at the corner sides. In this case, the stiffness due to shear wall lengths should also be considered. When the number of stories changes from 6 to 12 , displacements and interstory drifts in buildings with the same number of stories is changing in such a way that the displacements are increasing at a level that can be tried 1 to 6 times. Relative stories are increasing in displacement, but the ratio remains as 1 to 3 times. When the shear walls are removed from the center part, it is seen that the displacement and the displacements are very high when looking at the 6 storey building. This shows us how much the shear walls reduce relative story drifts in the combined systems.
In the determination of building performance gain from nonlinear static analysis methods, the performance levels of the structure are interpreted taking into consideration the section turn, torsion and relative interstory drift values in the system to be used in the element to be used. For the shear wall-frame type system, considering the rotations occurring in the plastic joints; the performance level of the structure remains in life safety level while the level of performance is in the level of performance of safety but closer to the level of immediate use in view of the relative story drifts that occur in the structure. As a result, it is observed that the structure of the section rotations formed for the analyzed structures is more effective in determining the performance than the relative story displacement. Plasticizing in columns usually occurs at the lower tips of the columns on the ground where the largest earthquake moments occur, but not for beams. Plastic joints spread in the structure, they can be seen at different points. Shear wall- in a frame with a frame system, tendons tend to plasticize mostly in beams that transmit moments to the shear walls.

Relative story displacement rates are also found to be smaller in shear wall-frame type buildings as they are lowered to the lower stories only by frame type structure. It is an inevitable requirement to use reinforced concrete shear walls to design buildings resistant to seismic forces. When shear walls limit lateral displacements, they significantly reduce relative story displacements. For future works, design for shear wall-frame systems can be designed to be in the inner-middle part of shear wall structure system.

\section{References}

[1] Karageyik, C. (2010). Displacement-Based Seismic Rehabilitation of NonDuctile RC Frames with Added Shear Walls, The Middle East Technical University, Ankara, Turkey.

[2] Elrodesly A. A.S.E. (2007). Displacement-Based Seismic Design of Reinforced Concrete Shear Wall Buildings, Ottowa, Canada.

[3] İdeSTATİK 8.0 Yapısal Statik Analiz Programı, İdeYAPI Bilgisayar Destekli Tasarım Mühendislik Danışmanlık ve Taahüt Limited Şirketi, Bursa.

[4] ATC 40 (1996). Seismic Evaluation and Retrofit of Concrete Buildings, Applied Technology Council, California.

[5] FEMA 273, (1997). NEHRP Guidelines for Seismic Rehabilitation of Buildings, Federal Emergency Management Agency, Washington, DC.

[6] FEMA 356, (1997). Prestandard and commentary for Seismic Rehabilitation of Buildings, Federal Emergency Management Agency, Washington, DC. 
[7] FEMA 440, (2005). Static Seismic Analysis Procedures, Report prepared by the A.T.C. for the Federal Emergency Management Agency, Washington, DC.

[8] ASCE/SEI 41, (2007). Seismic Raehabilitation of Existing Buildings (ASCE/SEI 41-06)., American Society of civil Engineers, Reston, VA.

[9] CEN (1998). Eurocode EC8 - Design of structures for earthquake resistance - Part 1: General rules, seismic actions and rules for buildings, prEN-1998-1, Comite Europeen de Normalization, Brussels, Belgium.

[10] TEC (Turkish Earthquake Code). 2007. Regulations on structures constructed in disaster regions. Ministry of Public Works and Resettlement, Ankara, Turkey.

[11] TBDY (Turkish Building Earthquake Code). 2018. Specifications for building design under earthquake effects. Disaster and Emergency Management Presidency, Ankara, Turkey:

[12] Shibata A. and Sozen M.A. (1976). Substitute-Structure Method for Seismic Design in R/C. Journal of the Structural Division. 102(1), 1-18.

[13] Priestley M. J, N. and Kowalsky M. J. (2000). Direct displacement-based seismic design of concrete buildings. Bulletin of the New Zealand National Society for Earthquake Engineering, 33: 421-444.

[14] Priestley, M.J.N. (2003) Performance Based Seismic Design of Concrete Buildings. Bull. NZSEE. (In Press)

[15] Hong S.G. and Cho B. H., (2001). Displacement- Based Design and Assessment of Structural walls. KEERC-MAE Joint Seminar on Risk Mitigation for Regions of Modareta Seismicity, University of Illinois at Urbana-Champaign, Urbana.

[16] Priestley M.J.N., Calvi G.M., Kowalsky M.j. (2007), Displacement-Based Seismic Design of Structures, Pavia, İtaly. DOI:10.1193/1.2932170

[17] Sullivan T.J., Priestley M.J.N. and Calvi G.M. (2006). Direct Displacement-Based Design of Frame - Wall Structures, Journal of Earthquake Engineering. Vol. 10, Issue sup001, 91-124. https://doi.org/10.1080/ $\underline{13632460609350630}$

[18] Kowalsky M.J., (1997). Direct Displacement Based Design: A Seismic Design Methodology and its application to Concrete Bridges, Ph.D. Thesis, University of California.

[19] Malekpour S., Ghaffarzadeh H. and Dashti F., (2013a). Direct displacement-based design of steel-braced reinforced concrete frames. Structural Design of Tall and Special Buildings. 22(18), 1422-1438. DOI: $\underline{10.1002 / \text { tal.1028. }}$.

[20] Malekpour S, Dashti F, (2013b). Application of the Direct Displacement Based Design Methodology for Different Types of RC Structural Systems, International Journal of Concrete Structures and Materials, 7(2), 135153. DOI 10.1007/s40069-013-0043-2.
[21] Karimzade N.A., Aktaş E. (2016). Performance- Based Seismic Design of Reinforced Concrete Frame Buildings: A Direct Displacement-Based Approach, Izmir Yüksek Teknoloji Enstitüsü, İzmir, Turkey.

[22] Abhyuday T., (2017). Fundamentals of Direct Displacement Based Design Procedure - A Brief Introduction, Disaster Advances, 10 (6), 40-43.

[23] Lopes G. C., Vicente R., Ferreira T. M., Azenha M., Estevao J., (2020). Displacement-based seismic performance evaluation and vulnerability assessment of buildings: The N2 method revisited, Structures 24, 41-49. https://doi.org/10.1016/j.istruc.2019.12.028.

[24] Yan L., Gong J., (2019), Development of displacement profiles for direct displacement based seismic design of regular reinforced concrete frame structures, Engineering Structures, 190, 223-237. $\quad$ https://doi.org/10.1016/ j.engstruct.2019.04.015

[25] Lu Y., Hajirasouliha I., Marshall A. M. (2018). Direct displacement-based seismic design of flexible-base structures subjected to pulse-like ground motions, Engineering Structures, 168, 276-289. https://doi.org/10.1016/j.engstruct.2018.04.079

[26] Öztürk T. (2005). Betonarme Binalarda Deprem Perdelerinin Yerleşimi ve Tasarımı, IMO İstanbul Şubesi Meslekiçi Eğitim Kursları.

[27] Garcia R., Sullivan T.J. and Corte G.D., (2010). Development of a Displacement Based Design Method for Steel Frame-RC Wall Buildings. Journal of Earthquake Engineering, 14(2), 252-277.

https://doi.org/10.1080/13632460902995138

[28] Arslan M.H, Köken A. (2008). BinalarınYapısal Performansının Statik İtme Analizi İle Belirlenmesi, Yap Teknolojileri Elektronik Dergisi, 4 (2), 71-84. 